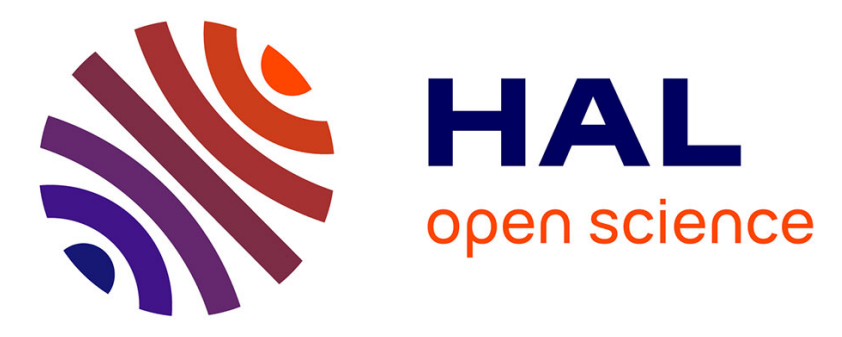

\title{
Waste-glass recycling: A step toward microwave applications
}

\author{
Ratiba Benzerga, Vincent Laur, Ronan Lebullenger, Laurent Le Gendre, \\ Sébastien Genty, Ala Sharaiha, Patrick Queffelec
}

\section{To cite this version:}

Ratiba Benzerga, Vincent Laur, Ronan Lebullenger, Laurent Le Gendre, Sébastien Genty, et al.. Waste-glass recycling: A step toward microwave applications. Materials Research Bulletin, 2015, 67, pp.261-265. 10.1016/j.materresbull.2014.07.037 . hal-01058342

\section{HAL Id: hal-01058342 https://hal.science/hal-01058342}

Submitted on 21 Nov 2014

HAL is a multi-disciplinary open access archive for the deposit and dissemination of scientific research documents, whether they are published or not. The documents may come from teaching and research institutions in France or abroad, or from public or private research centers.
L'archive ouverte pluridisciplinaire HAL, est destinée au dépôt et à la diffusion de documents scientifiques de niveau recherche, publiés ou non, émanant des établissements d'enseignement et de recherche français ou étrangers, des laboratoires publics ou privés. 


\title{
Waste-glass recycling: a step towards microwave applications
}

Ratiba Benzerga ${ }^{\mathrm{a}, *}$, Vincent Laur ${ }^{\mathrm{b}}$, Ronan Lebullenger ${ }^{\mathrm{c}}$, Laurent Le Gendre ${ }^{\mathrm{a}}$, S. Genty ${ }^{\mathrm{c}}$, Ala Sharaiha ${ }^{a}$, Patrick Queffelec ${ }^{b}$

${ }^{a}$ Institut d'Electronique et de Télécommunications de Rennes (IETR-UMR CNRS 6164), Université de Rennes 1, IUT de Saint Brieuc, 18 rue Henri Wallon, 22004 Saint-Brieuc, France

${ }^{b}$ Laboratoire des Sciences et Techniques de l'Information, de la Communication et de la Connaissance (Lab-STICC-UMR CNRS 6285), Université de Bretagne Occidentale, 6 avenue Le Gorgeu, CS93837, 29238 Brest Cedex 3, France

${ }^{c}$ Institut des Sciences Chimiques de Rennes (ISCR-UMR CNRS 6226), Université de Rennes 1, 35042 Rennes Cedex. France

* Corresponding author: Ratiba Benzerga, IETR- IUT Saint Brieuc, 18 rue Henri Wallon, 22000 Saint Brieuc, France, +33(0)296609661, ratiba.benzerga@univ-rennes1.fr, http://www.ietr.fr

Key Words - Dielectric properties; Glasses; Inorganic compounds.

\begin{abstract}
This study deals with microwave properties of glass foams prepared from glass industrial waste. Two types of cullets (one from soda-lime silicate glasses and the other from Cathodic Ray Tubes - CRT) have been combined with different foaming agents $(\mathrm{C}, \mathrm{SiC}, \mathrm{AlN})$. Glass foams electromagnetic properties are primarily determined by their apparent density as well as by the nature of the foaming agent. Foams, blown with carbon as foaming agent, present high dielectric loss and could be used as green electromagnetic absorbent in building industry.
\end{abstract}




\section{Introduction}

In times of growing energy and products consumption worldwide, the availability of raw materials becomes core to business and management processes. Waste recycling restricts the negative impact of human industrial activities on the planet by reducing industrial raw material needs. In the past few decades, numerous recycling processes have developed with the full support of the European Union [1]. Waste recycling is yet a standard practice and has become a fully-fledged segment of the industrial economy.

Among the different types of raw materials, the packaging glass recycling chain has proven to be an effective model. From 1974, driven by the glass industry, container glass recycling (bottles, jars ...) has been a great success. Recycling rates of this kind of hollow glass achieve now an efficiency of more than $70 \%$. Other types of glass compositions, often polluted with heavy metals, pose a tougher problem. This is particularly the case of Cathode Ray Tubes (CRT) found in TV screens and monitors or Soda Lime Silicate glass (SLS) from the automotive industries.

Over a number of years, recycling processes have been developed to produce glass foams [2,3]. While these materials are mostly marketed for thermal and/or acoustic insulation, recent works have shown that those foams could be used in innovative applications (photocatalyst support for hydrocarbon degradation) [2]. In this study, we will focus on the microwave properties of those recycled glass foams for potential new uses in the telecommunication area.

\section{Synthesis of glass foams}

The expansion of the glass foams is performed through off-gassing $\left(\mathrm{CO}_{2}\right.$ or $\left.\mathrm{N}_{2}\right)$ within the glassy matrix for temperatures above the Littleton point $\left(\mathrm{T}>800{ }^{\circ} \mathrm{C}\right.$ ). The pre-introduced foaming agent (or a combination of agents) is partially degraded, producing a gas, close to the softening temperature of the glass. Bubbles trapped within the viscous glass lead to a cellular material having a density that depends 
from the nature and the amount of the foaming agent(s), the glass composition and the operating temperature.

The cullet (CRT and/or SLS), pre-dried at $150^{\circ} \mathrm{C}$ for $12 \mathrm{~h}$, is milled together with the foaming agent (carbon C, Silicon Carbide SiC, Aluminum Nitride AlN or a combination thereof). The resulting mixture is transferred to a heat resistant steel mold and heated at the operating temperature $\left(\mathrm{T}=850^{\circ} \mathrm{C}\right)$ during $30 \mathrm{~min}$.

Table 1 summarizes the synthesis parameters (cullet type and foaming agent) and apparent density of the elaborated foams. Two sets of experiments were conducted; the first one (Samples 01 - 06) to determine the impact of the waste glass type and the second one (Samples 06 - 11) to measure the influence of the foaming agent nature. In every case, the mass fraction percentage of the blowing agent (pure or combined) does not exceed $4 \mathrm{wt} \%$ of the batch.

Table 1. Synthesis parameters (cullet type and foaming agent) and apparent density. The different cullet proportions are calculated as the percentage by weight.

\begin{tabular}{|c|c|c|c|}
\hline Samples & Cullet & Foaming agent & $d_{\text {app }}\left(\right.$ g.cm $\left.^{-3}\right)$ \\
\hline Smp-01 & $\operatorname{SLS}(100 \%)-\operatorname{CRT}(0 \%)$ & \multirow{5}{*}{ AlN } & 0.47 \\
\hline Smp-02 & $(70 \%)-\quad(30 \%)$ & & 0.43 \\
\hline Smp-03 & $(50 \%)-\quad(50 \%)$ & & 0.37 \\
\hline Smp-04 & $(30 \%)-\quad(70 \%)$ & & 0.34 \\
\hline Smp-05 & $(0 \%)-\quad(100 \%)$ & & 0.36 \\
\hline Smp-06 & SLS (100\%) & $\operatorname{AlN}(50 \%)-\operatorname{SiC}(50 \%)$ & 0.77 \\
\hline Smp-07 & \multirow{5}{*}{ CRT $(100 \%)$} & AlN & 0.35 \\
\hline Smp-08 & & $\mathrm{C}$ & 0.85 \\
\hline Smp-09 & & $\mathrm{SiC}$ & 0.49 \\
\hline Smp-10 & & $\mathrm{C}(50 \%)-\mathrm{SiC}(50 \%)$ & 0.60 \\
\hline Smp-11 & & $\operatorname{AlN}(50 \%)-\operatorname{SiC}(50 \%)$ & 0.47 \\
\hline
\end{tabular}


Resulting glass foams can be described as a composite with a matrix consisting of glass and with reinforcing particles consisting of the unreacted remaining part of the foaming agent(s). In fact, in that process, only 20 to $30 \%$ of the pre-introduced foaming agent react and are involved, by decomposition and subsequent gas development, in the expansion process [2]. The unreacted part of the powder particles $(\mathrm{C}, \mathrm{AlN}, \mathrm{SiC})$ remains dispersed in the glassy walls of the cell material. For specific glass compositions (lead glass), a reduction of the modifier cations occurs and leads to metallic droplets precipitation [4].

\section{Method of micowave characterization}

The electromagnetic characterization of the foam glass samples (Fig. 1a) is done in the X-band frequency range $(8-12 \mathrm{GHz})$. Microwave measurements are carried out with an Agilent PNA E8664A network analyzer. A rectangular waveguide is used for the characterization of the foam samples.

Prior to taking measurements, a TRL (Through-Reflect-Line) calibration is performed to put the reference planes at the beginning of the waveguide section. A first measurement of vacuum is performed to take into account losses of the empty waveguide. The glass foam sample is cut to the dimension of the waveguide (22.86 X $\left.10.16 \times 20 \mathrm{~mm}^{3}\right)$, and then inserted into the waveguide section for the characterization (Figure 1.b).

Measured S-parameters of the samples, enables us to extract the microwave dielectric properties of the foam glasses (i.e relative permittivity $\varepsilon_{\mathrm{r}}$ and loss tangent $\tan \delta$ ) [5-7]. 


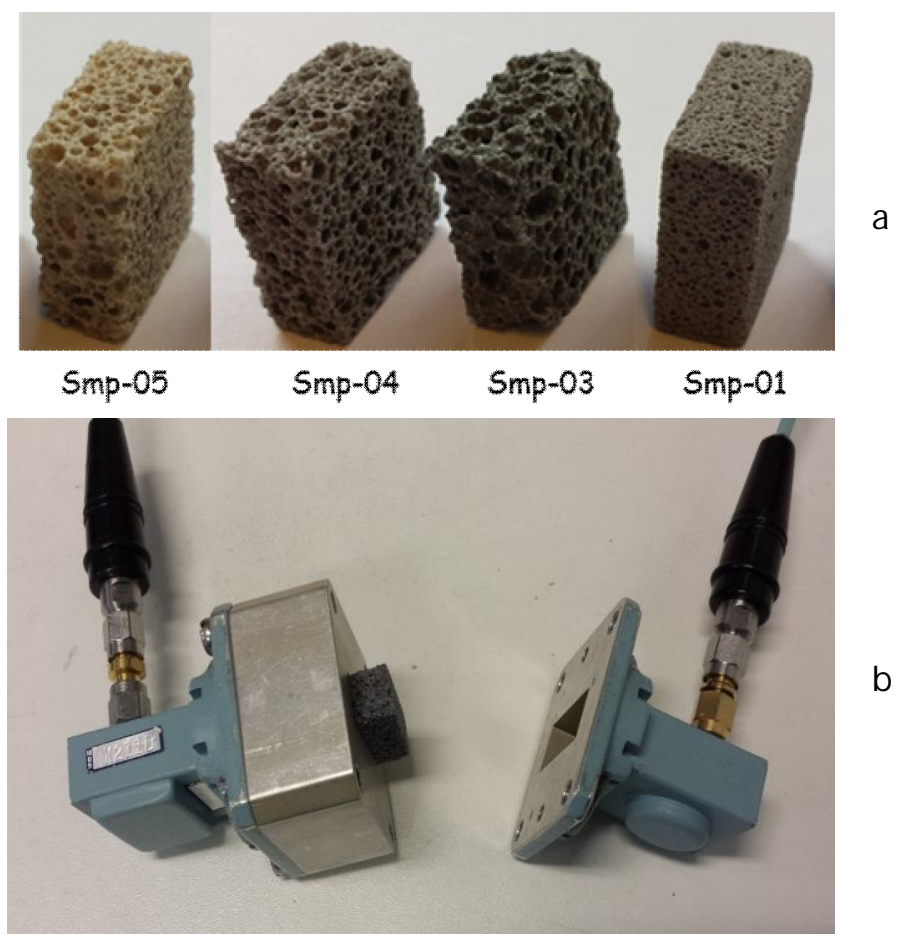

Fig. 1. Foam glass samples with different \%wt of CRT waste glass (a) and Microwave cell characterization (b)

\section{Physical and microwave properties of the glass foams}

Since no chemical component used possesses magnetic properties $\left(\mu^{*}=1\right)$, only dielectric results will be discussed. In this study, we will focus on the influence of the nature of the cullet (CRT or SLS) as well as that of the foaming agents $(\mathrm{C}, \mathrm{SiC}$ ou $\mathrm{AlN})$ used in this process.

Fig. 2 shows the glass foams dielectric constant (imaginary and real parts) as a function of the percentage by weight of CRT glass (foam blown with AIN as a foaming agent - Samples 01 to 05). Whatever the soda-lime-silica glass to CRT lead glass ratio in the batch, no significant changes in their dielectric performance have been noted. 


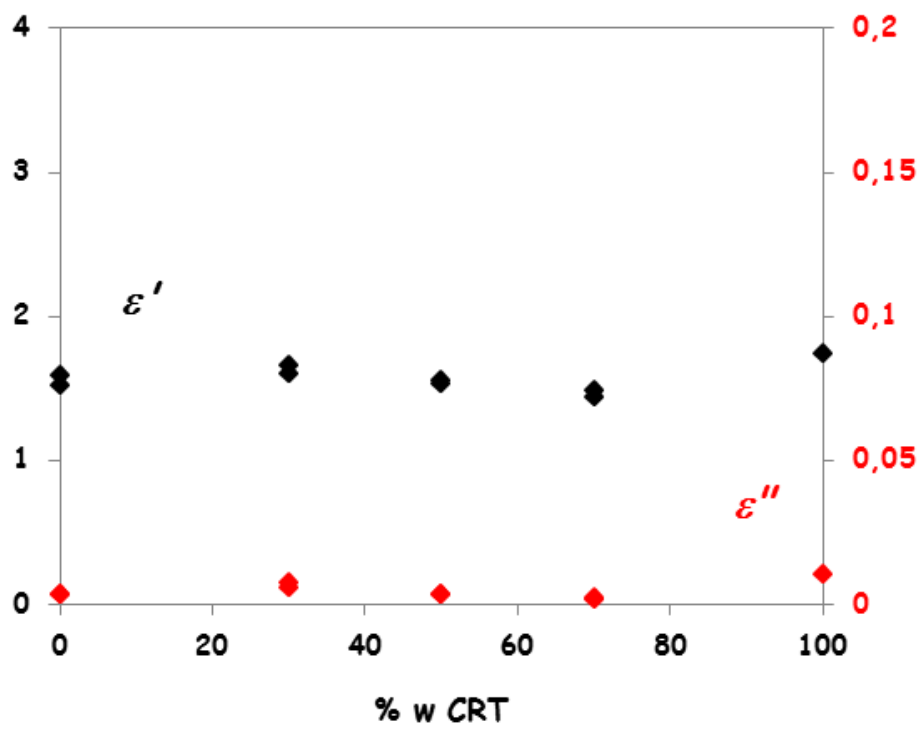

Fig. 2. Real and imaginary parts of the permittivity at $10 \mathrm{GHz}$ as a function of the percentage by weight of CRT glass.

Furthermore, apparent foams densities result from the cullet composition and the type of the foaming agent (Table 1). The apparent density of the foams increases with the SLS fraction in the glass mixture used. Pure SLS-based foam (Sample 01) shows a density of $0.47 \mathrm{~g} . \mathrm{cm}^{-3}$ while a pure CRT-based sample (Sample 05) has a lower density $\left(0.36 \mathrm{~g} . \mathrm{cm}^{-3}\right)$. The same observation has been made with samples prepared with $\mathrm{SiC}$ and $\mathrm{AlN}$ as foaming agents. In those conditions, a density $0.77 \mathrm{~g} . \mathrm{cm}^{-3}$ has been obtained starting from a pure SLS cullet (Sample 06) whereas a CRT-based foam (Sample 11) shows a density of 0.47 g.cm ${ }^{-3}$. Scanning Electron Microscopy (SEM) micrographs (Fig. 3) show that this density difference is reflected in an increase in the pore sizes (Sample 06 and Sample 11). In fact, although the bulk density of CRT glass $\left(2.85 \mathrm{~g} . \mathrm{cm}^{-3}\right)$ is higher than that of SLS glass $\left(2.5 \mathrm{~g} . \mathrm{cm}^{-3}\right)$, the presence of lead makes it more reactive to the foaming process [8]. In addition, at $850^{\circ} \mathrm{C}$, the viscosity of the CRT glass seems particularly well suited to the foaming process [9]. 
Furthermore, on the basis of the measures shown in Table 1 (Samples 01, 05, 06, 11), one can observe that $\mathrm{AlN}$ is a more efficient foaming agent than $\mathrm{SiC}$. In the light of these results, density is a key parameter that will drive the dielectric results.
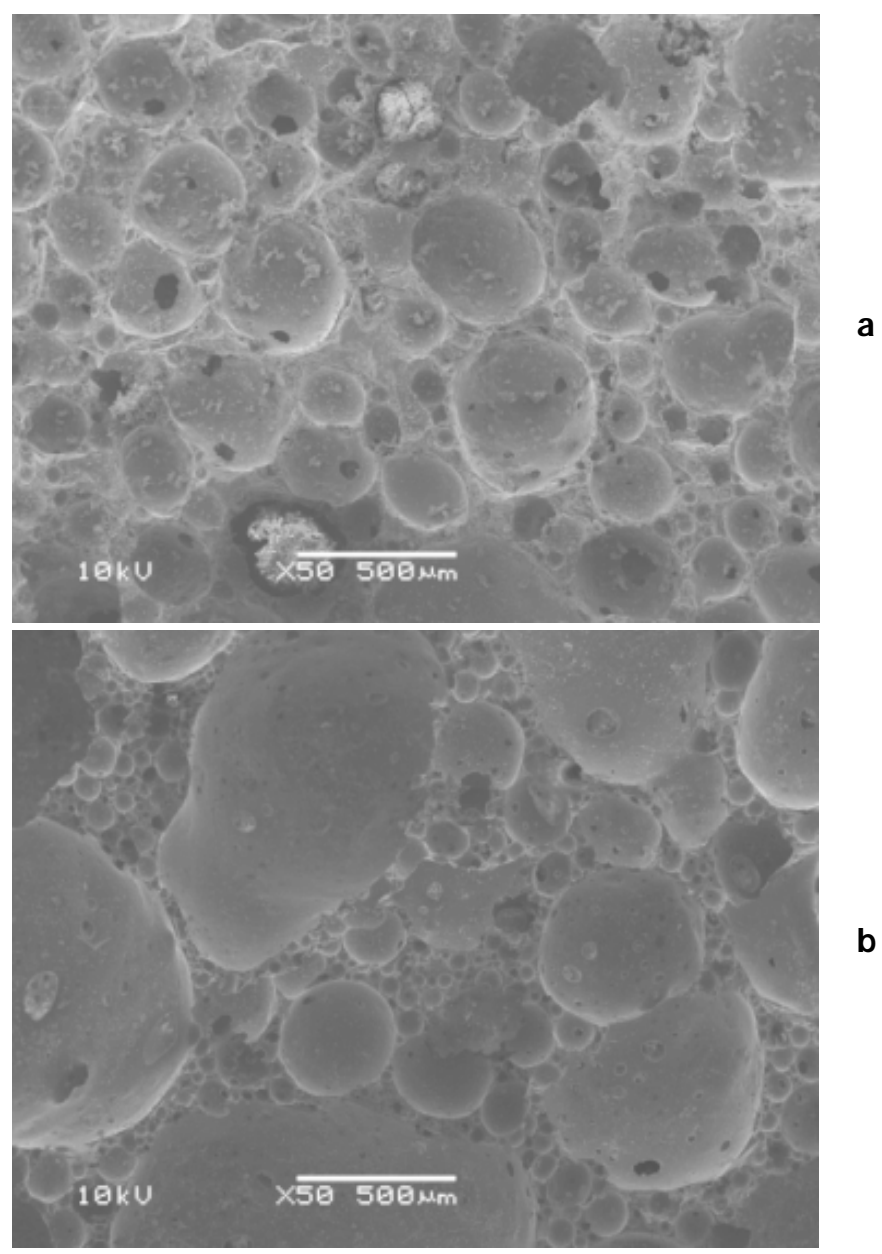

Fig. 3. SEM image of the samples Smp-06 based on SLS waste (a) and Smp-11 based on CRT waste (b). AlN and SiC are used as foaming agents.

Fig. 4 shows the dielectric properties of the glass foams as a function of their density, the origin of the glass waste (SLS or CRT) and foaming agent (AIN or SiC) is not specified. 


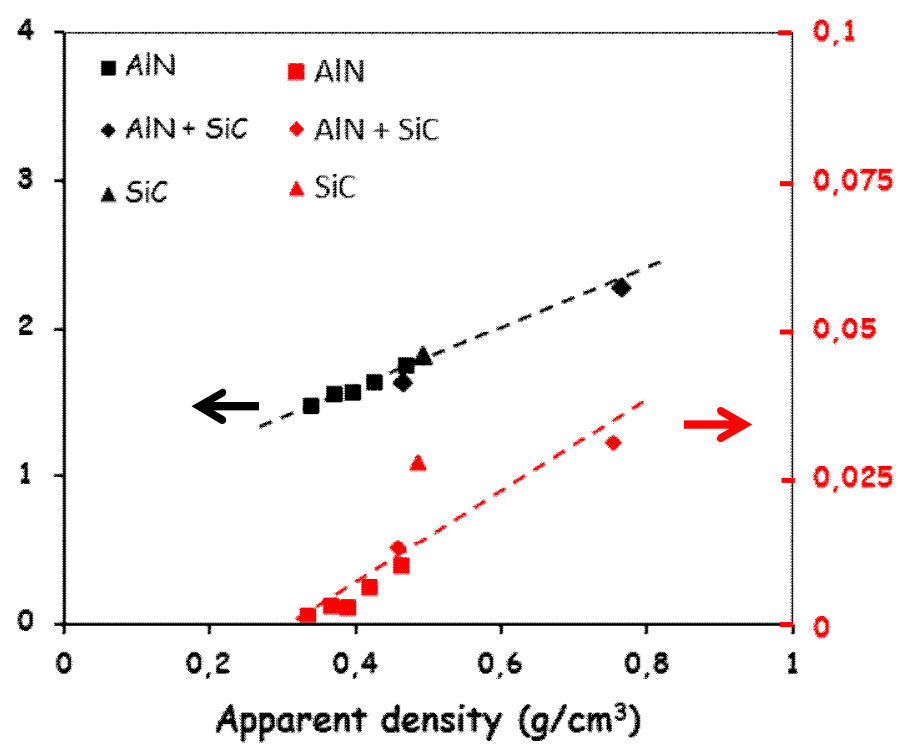

Fig. 4. Real and imaginary parts of the permittivity at $10 \mathrm{GHz}$ as a function of the foam density (foams produced with AlN, SiC or a combinaison of both).

Foams, produced with AIN, SiC or a combination of both, show permittivity values which increase linearly with their density (irrespective of the origin of the glass cullet). Measured at $10 \mathrm{GHz}$, permittivity values lie in a limited range: from 1.47 for a glass foam density of 0.34 g.cm $\mathrm{cm}^{-3}$ to 2.27 for a glass foam density of $0.77 \mathrm{~g} . \mathrm{cm}^{-3}$. On the same density range, the extracted values of the imaginary part of the complex permittivity (Fig. 3) increase from $0,002\left(\tan \delta=1.310^{-3}\right)$ to $0.031\left(\tan \delta=1.410^{-2}\right)$.

The small dielectric losses of those inorganic foams, associated with their interesting mechanical properties (with regard to the high porosity of those materials) suggest microwave applications especially in the field of antenna technologies. It can be noted that those foams present a low density in comparison to those of the materials conventionally used in electronics $\left(\rho_{\text {Teflon }}=2.15 \mathrm{~g} . \mathrm{cm}^{-3}\right.$, $\rho_{\text {Alumi- }}$ $\left.\mathrm{na}=3.97 \mathrm{~g} \cdot \mathrm{cm}^{-3}\right)$. Moreover, glass foams will ensure fire-performance significantly higher than that of organic polymer foams. 
In the case of the use of a carbon-containing foaming agent (pure carbon powder with an amount of \%wt $\mathrm{C}=1$; or a mixture $\mathrm{SiC} / \mathrm{C}$ that leads to a \%wt $\mathrm{C}$ of 0.5 ; c.f. Table $1 /$ Sample $08 \& 10$ ), dielectric properties drastically change. Microwave measurements performed on loaded waveguides show a significant increase in the absorption $A$ (defined by the following formula), $S_{11}$ and $S_{21}$ are respectively the reflection and transmission parameters measured in the waveguide:

$$
A=1-\left|S_{11}^{2}\right|-\left|S_{21}^{2}\right|
$$

As one can see in Fig. 5, absorption of the foams produced with pure SiC (Sample 09) remains at around $10 \%$ in the $8-12 \mathrm{GHz}$ frequency range. By using a carbon-containing foaming agent, higher values of absorption can be obtained. As indicated in Figure 5, absorption reaches $70 \%$ at $8 \mathrm{GHz}$ or $84 \%$ at $12 \mathrm{GHz}$ for foam samples with the same length $(18 \mathrm{~mm})$ obtained with the aid of a C/SiC mixture (Sample 10). Pure carbon as a foaming agent leads to comparable results; absorption values of CRT-glass foams expanded with pure carbon (1\%wt) cannot be directly compared due to samples sizes difference.

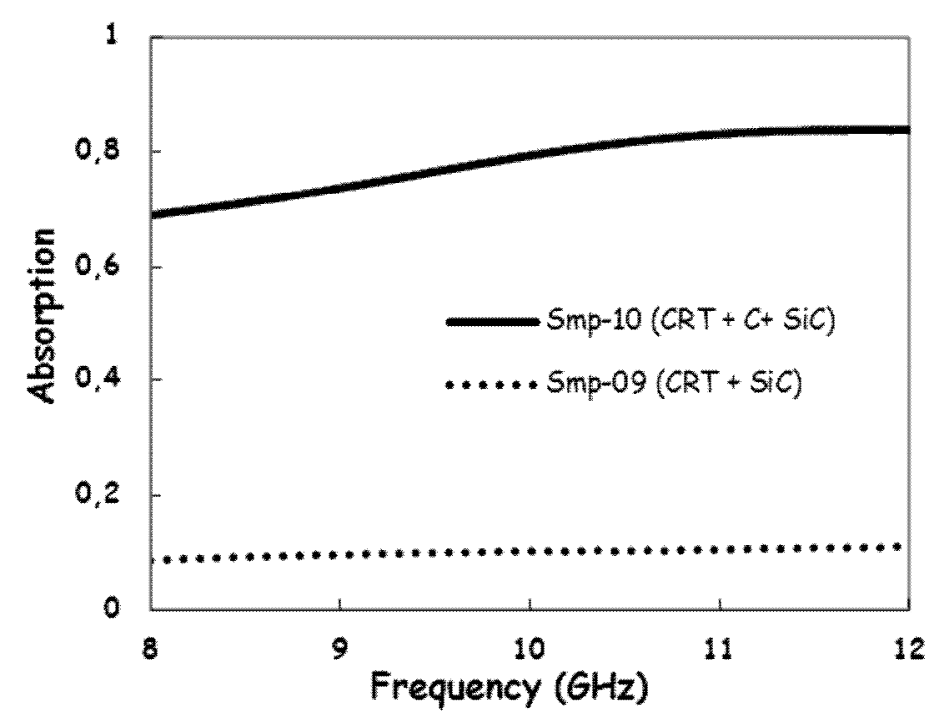

Fig. 5. Absorption measured through a rectangular waveguide loaded with CRT-glass foams expanded with different foaming agents ( $\mathrm{SiC}$ and $\mathrm{C}+\mathrm{SiC})$. 
An analysis of the dielectric response obtained on the foam glass loaded waveguide shows that the permittivity is drastically higher when the carbon is present (Fig. 6.a). The impact of the use of carbon is also significant on the imaginary part of the permittivity (Figure 6.b) which an increase of around 100-fold. That way, we obtain foams with dielectric loss of 0.37 at $10 \mathrm{GHz}$.
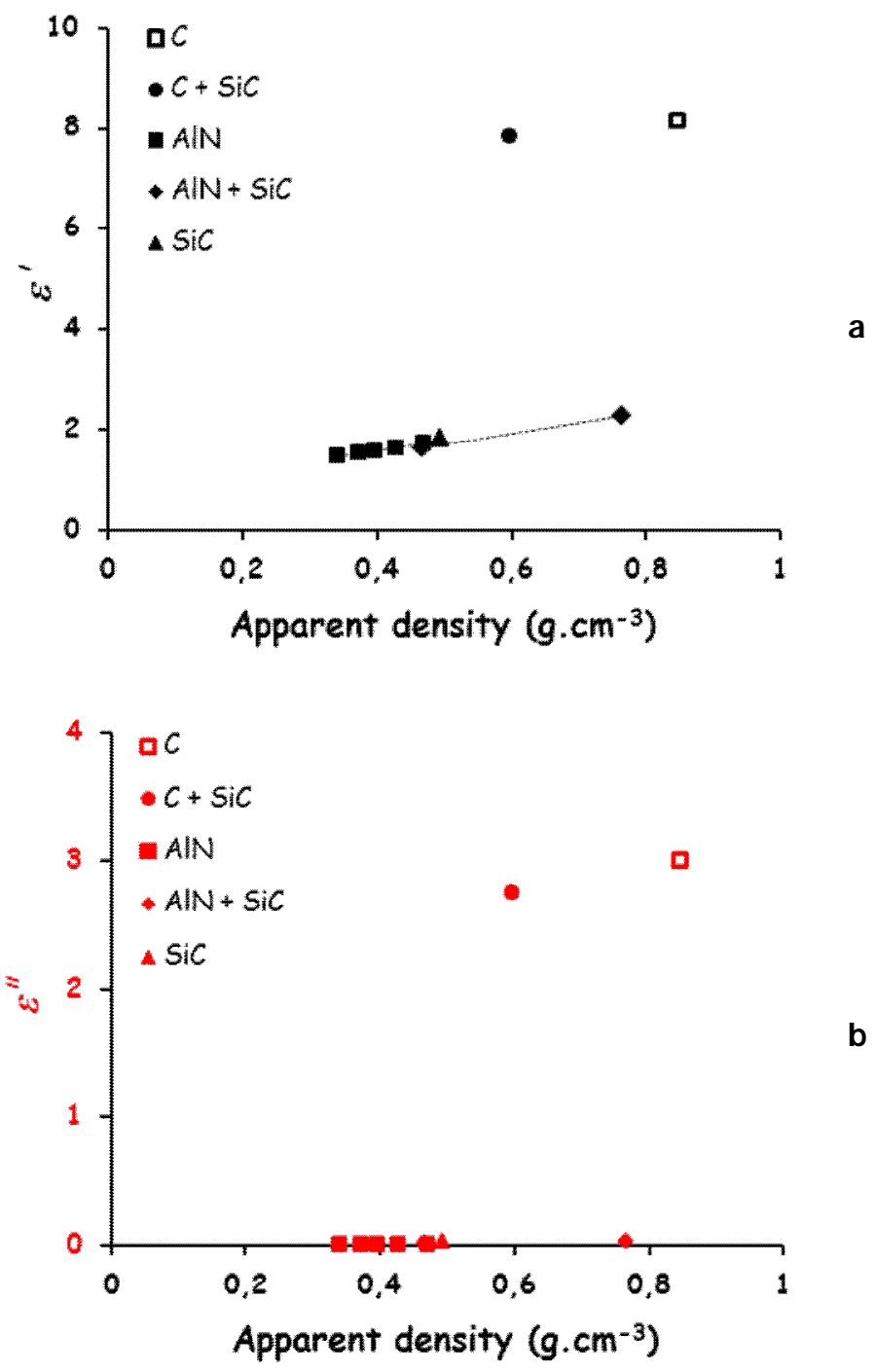

Fig. 6. Real (a) and imaginary (b) parts of the permittivity at $10 \mathrm{GHz}$ as a function of the foam density for different foaming agents (AlN, SiC and C). 
Those losses may have a dual origin. The major part (between 70 and $80 \%$ ) of the graphite initially introduced in the batch has not been involved in the oxidation-reduction reaction responsible for the expansion [2]. It has been shown that the carbon fraction remains stable in the viscous glassy liquid at this temperature [10]. Recent works of X. Li et al. [10] on dielectric properties of $1 \mathrm{wt} \%$ carbon-filled alumino-borosilicate glasses present a comparable absorption in the $\mathrm{X}$-band. On the other hand, $\mathrm{Pb}^{2+}$ ions, contained as modifiers in the CRT glass, reduce above $800^{\circ} \mathrm{C}$ and precipitate in the form of metallic droplets [4]. This metallic fraction could contribute to a portion of the dielectric loss.

The microstructure of the foams produced from a mixture of CRT-glass and a C-containing foaming agent has been examined by Scanning Electron Microscopy. Fig. 7 shows the SEM (backscattered electrons [11]) micrograph of a CRT matrix expanded with pure C (Sample 08 - see Table1). One can clearly see particles with a high atomic number (white) that can be identified as lead droplets $\left(\mathrm{Pb}^{0}\right)$.

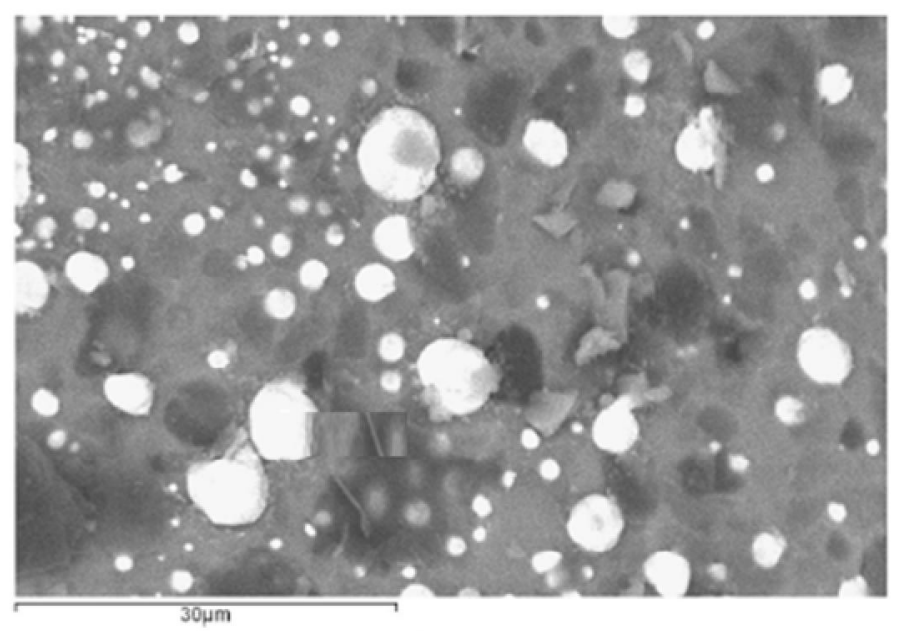

Fig. 7. SEM Image of Sample $08(\mathrm{CRT}+\mathrm{C})$ - backscattered electrons.

The presence of metallic lead has been confirmed by X-Ray Diffraction (XRD). XRD patterns of samples 07 and 08 are shown on Figure 8. On the sample produced with carbon, one can identify, emerging from the broad hump of the glassy matrix, the contributions of the crystalline form of silica 
i.e. quartz (partial crystallization during the cooling off process) and the metallic lead. This lead signature can be seen on the CRT-based foams prepared with AlN or SiC (Sample 07 - Fig.7), i.e. without carbon, for with the dielectric loss is low.

It follows, therefore, that the residual carbon fraction is the main source of the electromagnetic absorption in this frequency range. Given the relatively high levels of absorption of those foams, including carbon particles is an efficient way to synthesize EM absorbers or power loads from recycled wastes.
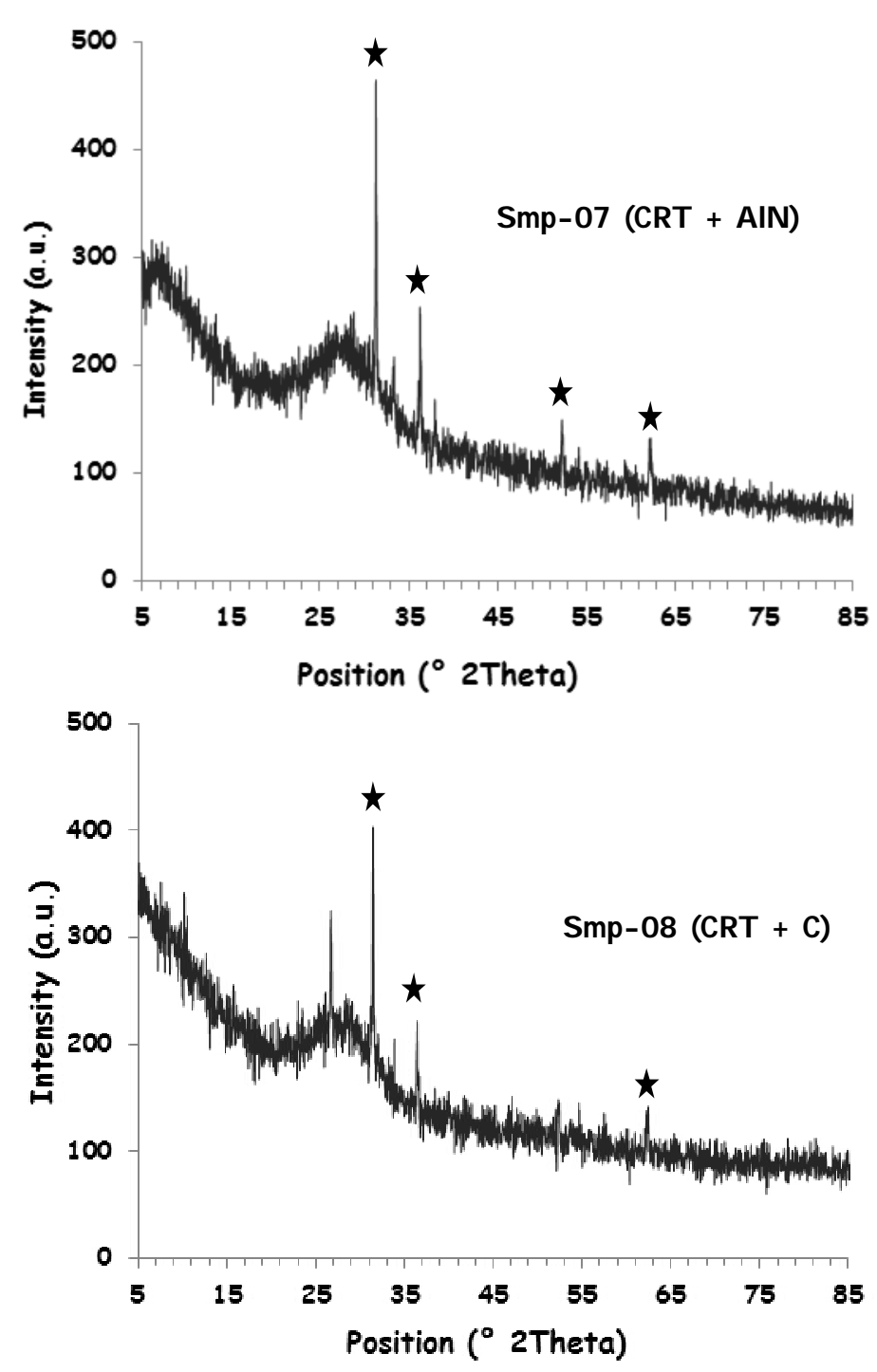

Fig. 8. X-ray diffractogram of samples 07 and 08. 


\section{Conclusion}

Dielectric properties of inorganic foams, obtained through recycling industrial glass waste, have been measured in the microwave band. The use of a carbide or a nitride as a foaming agent ( $\mathrm{SiC}$ or $\mathrm{AlN}$ ) leads to low loss and homogenous foams that could be used in antenna devices. Carbon has been used also to make the glass swell but only a fraction of this organic compound reacts. Then, the EMabsorbent residual fraction enhances the microwave absorption properties. As the raw material is a recycled culled, there is a significant potential for development for low-cost C-filled glass foams. In order to broaden the spectrum of creative potential applications, EM properties of those foams will be tested in an expanded frequency range.

\section{REFERENCES}

[1] Rapport Annuel Eco-Systèmes, www.eco-systemes.fr/documents/Rapport_annuel_Ecosystemes_2012.pdf

[2] R. Lebullenger, S. Chenu, J. Rocherullé, O. Merdrignac-Conanec, F. Cheviré, F. Tessier, A. Bouzaza, S. Brosillon, "Glass foams for environmental applications" Journal of Non-Crystaline Solids 356 (2010) 2562-2568

[3] H. R.Fernandes, Fernanda Andreola, L. Barbieri, I. Lancellotti, M. J.Pascual, J. M. F.Ferreira, "The use of eggs hells to produce Cathode Ray Tube (CRT) glass foams" Ceramics International, 39 (2013) 9071-9078

[4] F. Mear, P. Yot, M. Ribes "Effects of temperature, reaction time and reducing agent content on the synthesis of macroporous foam glasses from waste funnel glasses" Materials Letters, 60, 7 (2006) 929-934

[5] W.B. Weir, "Automatic measurement of complex dielectric constant and permeability at microwave frequencies" Proceedings of the IEEE 62 (1974) 33-36 
[6] A.M. Nicolson, G.F. Ross, "Measurement of the intrinsic properties of materials by time domain techniques" IEEE Trans. Instr. Meas. 1 (1970) 377-382

[7] J. Baker-Jarvis, M.D. Janezic, J.H. Grosvenor, R.G. Geyer, “Transmission/Reflection and ShortCircuit Line Methods for Measuring Permittivity and Permeability" Natl. Inst. Stand. Technol. Tech. Note 1355-R (1993)

[8] F. Mear, P. Yot, M. Cambon, M. Ribes, "Elaboration and characterisation of foam glass from cathode ray tubes" Advances in Applied Ceramics 104 (2005) 123-130

[9] F. Mear, P. Yot, M. Cambon, M. Ribes, "The characterization of waste cathode-ray tube glass",Waste Management 26 (2006) 1468-1476

[10] Xiuhua Li, Dongsheng Lv, Kuo Chen, "Effets of graphite additive on dielectric properties and microwave absorption properties of zinc-containing foam glass" Journal of Non-Crystalline Solids, 358 (2012) 2917-2921

[11] J.P. Eberhart, Analyse structurale et chimique des matériaux, Nouvelle. Dunod, 1997 